\title{
Amylase Crystalloids on Fine-Needle Aspiration of the Salivary Gland
}

\author{
Tükürük Bezi İnce İğne Aspirasyonunda Amilaz Kristaloitleri
}

\author{
İrem PAKER, Murat ANLAR, Nebiyye GENEL, Murat ALPER \\ Department of Pathology, M.H. Dışkapı Yıldırım Beyazıt Education and Research Hospital, ANKARA, TURKEY
}

\begin{abstract}
Amylase crystalloids is one of the several types of crystalline structures that can be seen in non-neoplastic and neoplastic salivary gland lesions. Here, a 60-year-old woman with an infraauricular mass existing for two years is presented.

On ultrasound a cystic mass, $1 \mathrm{~cm}$ in diameter was detected in the tail of right parotid gland. Clear and mucoid fluid was obtained from the mass by fine-needle aspiration. Smears showed numerous rhomboid, rectangular or rod-shaped, non-birefringent crystalloid structures and a few acinar cell groups in a mucoid background rich in polymorphonuclear leucocytes and lymphoctes. It was reported as cystic sialadenitis with amylase crystalloids. In the four-month follow-up, there was no recurrence of the mass.

Since encountered only in benign salivary gland lesions in the literature as in our case, observation of amylase crystalloids on fine-needle aspiration smears indicates a benign lesion and avoids unnecessary surgery.
\end{abstract}

Key Words: Amylase crystalloids, Salivary gland, Cytology öz

Amilaz kristaloitleri tükürük bezinin non-neoplastik ve neoplastik lezyonlarında görülebilen çeşitli kristaloit tiplerinden biridir. $\mathrm{Bu}$ makalede, infraauriküler bölgede iki senedir kitle şikayeti olan 60 yaşında kadın hasta sunuldu.

Ultrasonografik olarak sağ parotis bezi kuyruk kısmında $1 \mathrm{~cm}$ çapında kistik kitle saptandı. Kitleden ince iğne ile berrak, mukoid özellikte sıvı aspire edildi. Mikroskobik incelemede preparatlarda mukoid zeminde çok sayıda romboid, dikdörtgen veya çubuk şekilli, polarize 1şıkta refle vermeyen kristaloit yapılar, lenfositler ve nötrofillerden oluşan mikst inflamatuar hücreler ve tükürük bezine ait az sayıda asiner yapı gözlendi. Olgu amilaz kristaloitleri içeren kistik sialadenit olarak rapor edildi. Hastanın 4 aylık takibinde kitlede büyüme izlenmedi.

Sonuç olarak tükürük bezi ince iğne aspirasyonu materyalinde görülebilen amilaz kristaloitleri tanı için spesifik olmasa da literatüre göre ve sunulan olguda da olduğu gibi yalnızca benign lezyonlarda görülmesinden dolayı, hastayı gereksiz cerrahiden korumaktadır.

Anahtar Sözcükler: Amilaz kristaloitleri, Tükürük bezi, Sitoloji

\section{INTRODUCTION}

Amylase crystalloids are non-birefringent geometric, polygonal, rhomboid-shaped structures with pointed ends that stain orange using Papanicoloau stains, deep blue by Diff-Quik and pink by Hematoxylin-Eosin (H\&E) and range in size from 5 to $500 \mu \mathrm{m}$ (1-7). They were first observed by Takeda and Ishikawa in a human salivary duct cyst in 1983 (7). In 1993, Jayaram et al. first described crystalloids in fine-needle aspiration (FNA) smears from a parotid cyst (8). Amylase crystalloids can be seen in some cases of chronic sialadenitis as well as cystic lesions, $(1,2)$. Here, a case of cystic sialadenitis with amylase crystalloids is reported.

\section{CASE REPORT}

A 60-year-old woman presented with an infraauricular mass that had been present for 2 years. On ultrasound a cystic mass $1 \mathrm{~cm}$ in diameter was detected in the tail of right parotid gland. FNA was performed in the right infraauricular region by the cytopathologist using 27-gauge needles attached to a 10-ml syringe holder and a clear, mucoid fluid was obtained. Smears were either air-dried and stained with Diff-Quik or ethanol fixed for Papanicolaou stain.

The FNA smears revealed many geometric, multifaceted non-birefringent crystalloids varying in size. The crystalloids were rectangular, rhomboid and rod-shaped with pointed

Correspondence: İrem PAKER

Department of Pathology, M.H. Dışkapı Yıldırım Beyazıt Education and Research Hospital, ANKARA, TURKEY

E-mail: iremonur@yahoo.com Phone: +90 2324696969 
ends and parallel sides (Figure 1). They stained bright orange with Papanicolaou and deep blue with Diff-Quik. A mixed population of polymorphonuclear leucocytes and lymphocytes were scattered in a mucoid background (Figure 2A,B). Rare acinar cell groups were also present (Figure 3). The cytopathological diagnosis was reported as cystic sialadenitis with amylase crystalloids.

The patient did not undergo any surgical procedure. At follow-up 4 months after the diagnosis, there was no recurrence of the mass.

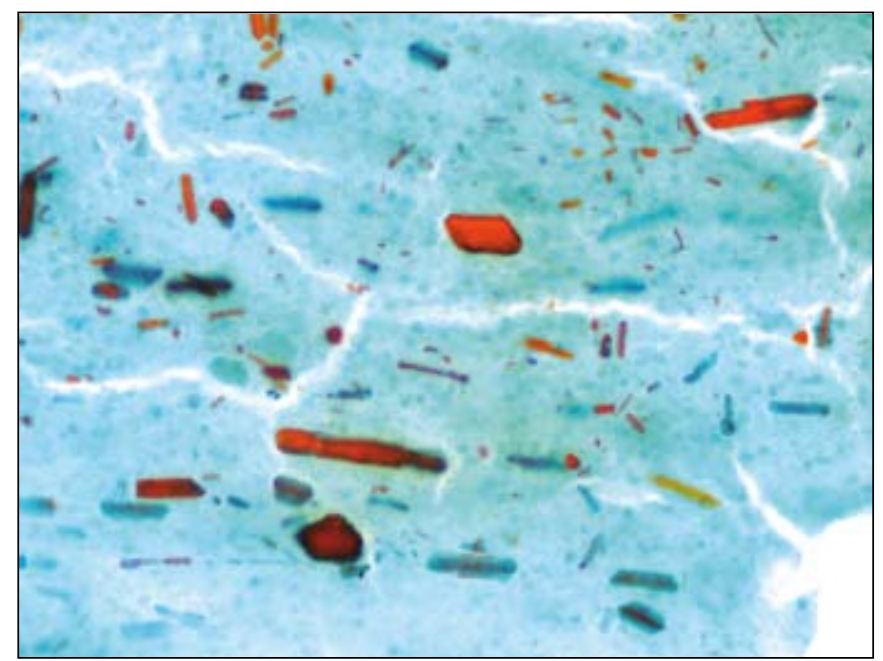

Figure 1: Many geometric, multifaceted non-birefringent crystalloids varying in size. Crystalloids were rectangular, rhomboid or rod-shaped with pointed ends and parallel sides (PAP, x200).

\section{DISCUSSION}

There are many types of crystalline structures such as amylase, tyrosine, collagenous crystalloids, oxalate and intraluminal crystals that can be seen in FNA smears of salivary gland lesions (1-16). It is important to differentiate other types of crystalloids from amylase crystalloids because they can be seen in malignant salivary gland tumors whereas amylase crystalloids are not $(9,17,18)$. By light microscopy, geometrically shaped amylase crystalloids can be easily discriminated from radially arranged needleshaped collagenous crystalloids and floret-shaped tyrosine crystalloids. (18-20). Intraluminal crystalloids are also nonbirefringent and geometrically shaped structures as well as amylase crystalloids. However, intraluminal crystalloids are composed of dense, amorphous, eosinophilic substance in contrast to more translucent amylase crystalloids. Moreover, amylase crystalloids can measure up to 500 $\mu \mathrm{m}$ whereas intraluminal crystalloids only measure up to $100 \mu \mathrm{m}(19,20)$. Crystalloids observed in our study were
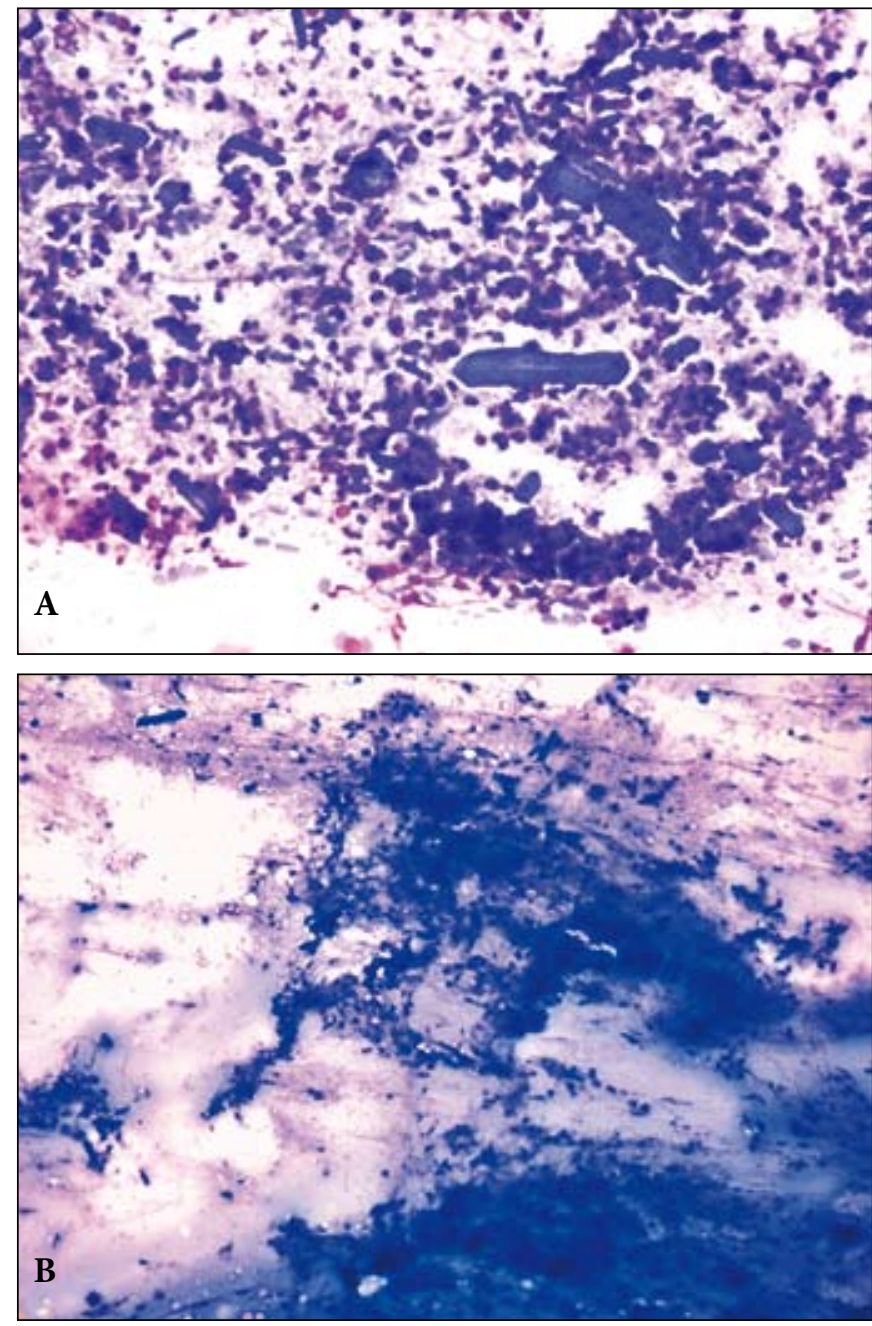

Figure 2: (A) Blue coloured crystalloids and numerous neutrophils in the background (Diff-Quik, x200). (B) Fine-needle aspiration smear had a mucoid background (Diff-Quik, x100).

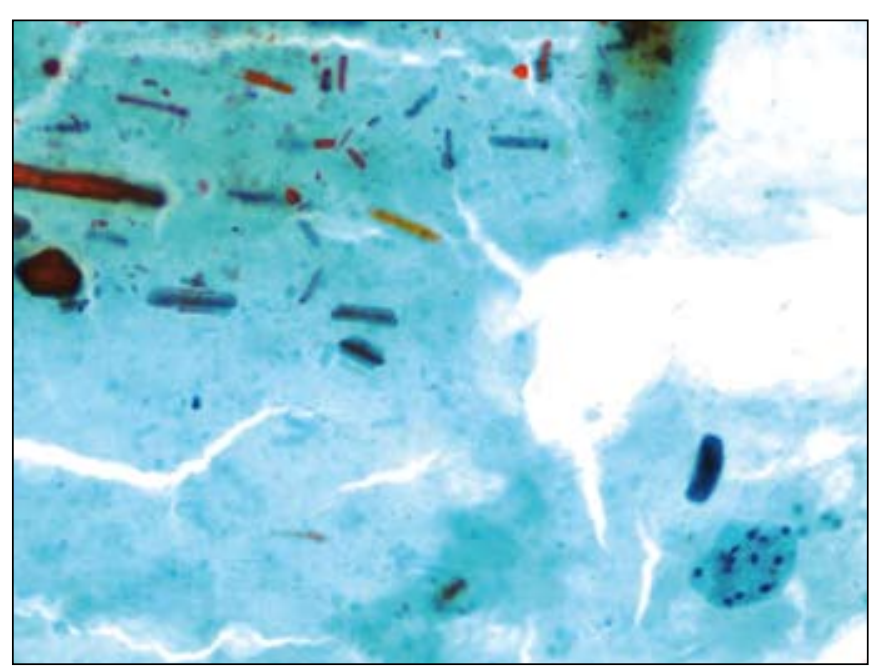

Figure 3: Amylase crystalloids and an acinar cell group (PAP, $\mathrm{x} 200)$. 
morphologically similar to $a$-amylase crystalloids described in the literature (3-8).

In their study, Takeda and Ishikawa analyzed crystalloids in a parotid duct cyst with scanning electron microscopy and electron probe X-ray microanalysis. They reported that amylase crystalloids may result from supersaturation of saliva and represent crystallized $\alpha$-amylase (7).

A review of the literature showed that amylase crystalloids have been mostly encountered in FNA smears of salivary glands with sialadenitis and sialolithiasis. Nasuti et al. said that amylase crystalloids should not be accepted as a noncellular marker for specific salivary gland pathology because there are reports that these crystalloids have been seen in various salivary gland lesions. They described amylase crystalloids in Warthin's tumor and oncocytic papillary cystadenoma (19). Lopez-Rios et al. stated that amylase crystalloids can be also seen in lymphoepithelial cysts (20).

Since amylase crystalloids have not been reported in any malignant tumor of the salivary gland until now, the occurrence of amylase crystalloids in FNA smears of the salivary gland favors a benign lesion. We should however always continue to pay attention to other cytomorphological features as a principle of cytopathology.

\section{REFERENCES}

1. Faquin WC, Powers $C N$ : Inflammatory patterns and lymphoma. In Rosenthal DL (Ed): Salivary Gland Cytopathology: Essentials in Cytopathology, Vol. 5, New York, Springer, 2008, 57-80

2. Tabbara SO: Salivary Glands. In Sidawy MK, Ali SZ (Eds): Fine Needle Aspiration Cytology: Foundations in Diagnostic Pathology. Philadelphia, Churchill Livingstone-Elsevier, 2007, $1-36$

3. López-Ríos F, Díaz-Bustamante T, Serrano-Egea A, Jiménez J, de Agustín P: Amylase crystalloids in salivary gland lesions: report of a case with a review of the literature. Diagn Cytopathol 2001, 25:59-62

4. Gerhard R, Vargas PA, da Cruz Perez DE, Fregnani ER: Fineneedle aspiration biopsy of parotid cystic lesion with crystalloid formation. Diagn Cytopathol 2005, 32:378-379
5. Pantanowitz L, Goulart RA, Jackie Cao Q: Salivary gland crystalloids. Diagn Cytopathol 2006, 34:749-750

6. Boutonnat J, Ducros V, Pinel C, Kieffer S, Favier A, Garin J, Seigneurin D: Identification of amylase crystalloids in cystic lesions of the parotid gland. Acta Cytol 2000, 44:51-56

7. Takeda Y, Ishikawa G: Crystalloids in salivary duct cysts of the human parotid gland. Scanning electron microscopical study with electron probe X-ray microanalysis. Virchows Arch A Pathol Anat Histopathol 1983, 399:41-48

8. Jayaram G, Khurana N, Basu S: Crystalloids in a cystic lesion of parotid salivary gland: diagnosis by fine-needle aspiration. Diagn Cytopathol 1993, 9:70-71

9. Cleveland DB, Cosgrove MM, Martin SE: Tyrosine-rich crystalloids in a fine needle aspirate of a polymorphous low grade adenocarcinoma of a minor salivary gland. A case report. Acta Cytol 1994, 38:247-251

10. Lemos LB, Baliga M, Brister T, Cason Z: Cytomorphology of tyrosine-rich crystalloids in fine needle aspirates of salivary gland adenomas. Acta Cytol 1997, 41:1709-1713

11. Skálová A, Michal M, Leivo I: Collagenous crystalloids and collagenous spherules in salivary gland tumors. A light microscopy and immunohistochemistry study. Cesk Patol 1993, 29:73-78

12. López-Ríos F, Ballestín C, Martínez-González MA, de Agustín $P$ : Tyrosine-rich crystals associated with oncocytic salivary gland neoplasms. Arch Pathol Lab Med 1998, 122:644-649

13. Lopez-Rios F, Ballestin C, Martinez-Gonzalez MA, de Agustin $P$ : Crystalloids and crystals in salivary gland lesions. Hum Pathol 1999, 30:1119-1120

14. Johnson FB, Oertel YC, Ammann K: Sialadenitis with crystalloid formation: a report of six cases diagnosed by fine-needle aspiration. Diagn Cytopathol 1995, 12:76-80

15. Jayaram G: Salivary cyst with crystalloids and oncocytic metaplasia. Diagn Cytopathol 1998, 19:147-148

16. Sáenz-Santamaría J, Catalina-Fernandéz I, Fernandez-Mera JJ: Sialadenitis with crystalloid formation. Fine needle aspiration cytodiagnosis of 15 cases. Acta Cytol 2003, 47:1-4

17. Ro JY, Mackay B, Batsakis JG, Cartwright J Jr: Intraluminal crystalloids in malignant salivary gland tumors (electron microscopic and X-ray microanalytic studies). J Laryngol Otol 1987, 101:1175-1181

18. Bellizzi AM, Mills SE: Collagenous crystalloids in myoepithelial carcinoma: report of a case and review of the literature. Am J Clin Pathol 2008, 130:355-362

19. Nasuti JF, Gupta PK, Fleisher SR, LiVolsi VA: Nontyrosine crystalloids in salivary gland lesions: report of seven cases with fine-needle aspiration cytology and follow-up surgical pathology. Diagn Cytopathol 2000, 22:167-171

20. López-Ríos F, Ballestín C, Martínez-González MA, Serrano R, de Agustín PP: Lymphoepithelial cyst with crystalloid formation. Cytologic features of two cases. Acta Cytol 1999, 43:277-280 